\title{
MIGRASI ORANG MINANGKABAU KE KOTA AMBON
}

\author{
Dominggus E. B. Saija, Elsina Titaley, Sulaiman Angkotasan \\ Program Studi Sosiologi Fakultas Ilmu Sosial dan Ilmu Politik \\ Universitas Pattimura \\ bradleysaija@gmail.com, elstitaleywfh@gmail.com
}

\begin{abstract}
Abstrak
Penulisan ini bertujuan untuk mendeskripsikan migrasi orang Minangkabau ke Kota Ambon. Metode yang digunakan dalam penelitian ini adalah metode penelitian kualitatif dengan lokasi peneitian di wilayah kecamatan Sirimau Kota Ambon. Kecamatan Sirimau adalah salah satu kecamatan dari lima kecamatan yang ada di Kota Ambon dan merupakan daerah pusat kota. Hasil penelitian menunjukkan bahwa generasi pertama orang Minangkabau yang bermigrasi ke Kota Ambon terjadi pada tahun 1920. Migrasi generasi pertama ke Kota Ambon bukan karena kehendak diri mereka sendiri atau sukarela (Voluntary) tetapi karena adanya determinasi penjajahan Belanda di daerah mereka pada waktu itu. Generasi ke-2 orang Minangkabau yang bermigrasi ke Kota Ambon yaitu pada tahun 1950 yang hanya berjumlah sekitar 20 orang. Generasi ke-2 yang bermigrasi pada saat itu, dapat juga dikatakan karena paksaan namun bukan lagi karena suatu penjajahan tetapi lebih mengarah karena ketidakstabilan situasi yang terjadi di daerah mereka. Ketidakstabilan yang di alami daerah mereka saat itu disebabkan oleh pertentangan antara adat dan Islam merupakan dua unsur budaya yang merupakan kekuatan dimiliki orang Minangkabau. Faktor lain yang juga menjadi penyebab orang Minangkabau migrasi ke Kota Ambon adalah kondisi Kota Ambon yang sejak dahulu telah dikenal sebagai kota perdagangan dan juga sifat orang Ambon yang konsumtif sehingga tentu saja sangat sesuai dengan jiwa sebagian besar orang Minangkabau yang berprofesi sebagai pedagang. Umumnya orang Minangkabau yang bermigrasi ke Kota Ambon menjalankan profesinya sebagai pedagang. Guna mempelancar usaha perdagangan mereka maka tempat di wilayah pusat Kota Ambon menjadi prioritas utama walaupun ada juga yang memilih tempat usaha di pinggiran Kota Ambon.
\end{abstract}

Kata Kunci: Orang Minangkabau, Migrasi, Budaya, Adat.

This study aims to describe the migration of the Minangkabau people to Ambon City. The research is a qualitative research method, located in the Sirimau sub-district, Ambon City. The result showed that the first generation of Minangkabau people who migrated to Ambon City was in 1920, because of the determination of Dutch colonialism in their area at that time, not because of their own willingness. The second generation of Minangkabau people who migrated to Ambon City 1950, was about 20 people. The second generation who migrated at that time, can also be said to be due to coercion but no longer because of colonialism but rather because of the instability of the situation that occurred in their area. The instability experienced by their area at that time was caused by the conflict between their costum and Islam, which are two cultural elements which are the strengths of the Minangkabau people. Another factor that also causes Minangkabau people to migrate to Ambon City is the condition of Ambon, which has long been known as a trading city and also the consumptive nature of Ambonese people, so of course it is very suitable for the souls of most Minangkabau people who work as traders. Generally, Minangkabau people who migrate to Ambon City carry out their profession as traders. In order to streamline their trading business, places in the central area of Ambon City are a top priority, although some have chosen business premises on the outskirts of Ambon City.

Keywords: Minangkabau people, Migration, Culture, Adat. 


\section{Pendahuluan.}

Penduduk suatu negara pada hakikatnya merupakan sumber daya yang sangat penting bagi pembangunan, sebab penduduk merupakan subjek ataupun objek pembangunan itu sendiri. Salah satu tanggung jawab utama negara dalam hubungan dengan kependudukan itu sendiri adalah meningkatkan kesejahteraan penduduk serta mengambil langkahlangkah pencegahan terhadap gangguan kesejahteraan (Soekanto, 2002:386). Kesejahteraan penduduk seringkali mengalami gangguan karena perubahan demografis yang tidak pernah dirasakan. Pada waktu Negara Indonesia masih menganut sistem sentralisasi, terlihat bahwa banyak sekali terjadi ketimpangan atau penyalahgunaan kebijakan yang dilakukan oleh pemerintah pusat terhadap daerah. Misalnya, dapat dirasakan oleh penduduk di tiap daerah bahwa pembangunan yang di laksanakan oleh pemerintah lebih mengutamakan atau lebih terfokus pada daerah pulau Jawa atau terlebih khusus pada daerah Kota Jakarta.

Dampak kebijakan ekonomi yang bertumpu pada efisiensi (pertumbuhan), adalah terjadi banyak disparitas (ketidaksamaan, ketidakseimbangan). Disparitas antara desakota, penghasilan masyarakat, maupun disparitas antara kawasan. Akibat yang lebih jauh adalah, ketidakadilan makin terasa. Disparitas golongan masyarakat sangat nampak, dan kondisi itu paling kontras di perkotaan (Ralahalu, 2006:103).

Tanpa disadari, situasi seperti ini akan mengakibatkan suatu kesenjangan yang sangat besar dalam kehidupan masyarakat kota. Di mana jumlah orang kaya makin bertambah banyak dan jumlah orang miskin pun makin bertambah. Hal ini merupakan suatu ironi yang nampak dalam kondisi penduduk wilayah perkotaan. Pada daerah kota-kota besar di Indonesia, kepadatan penduduk bukan lagi merupakan suatu hal yang baru, karena hal ini telah menjadi suatu masalah yang selalu ada dalam realitas kehidupan suatu kota. Kepadatan penduduk kota bisa disebabkan oleh faktor tingginya angka kelahiran bayi (hidup) dan perpindahan penduduk dari desa ke kota. Selain itu juga terdapat kesenjangan yang terjadi antara desa dan kota dalam berbagai aspek, telah melahirkan suatu dampak baru dalam pandangan masyarakat desa.

Berbagai fasilitas yang mendukung kemegahan suatu kota, mengakibatkan munculnya keinginan kuat dalam diri masyarakat desa untuk pergi atau merantau ke kota guna mendapatkan suatu kehidupan yang lebih baik. Semakin kuatnya pengaruh kemegahan suatu kota dengan berbagai fasilitas pendukungnya, menyebabkan tingginya niat masyarakat desa untuk melakukan penyerbuan (invasi) memasuki kota. Sebuah kota 
adalah suatu pemusatan penduduk dalam suatu wilayah yang sempit (Evers, 1982:10). Kota telah menjadi tempat atau pusat pertemuan penduduk atau masyarakat dari berbagai golongan etnis serta latar belakang kehidupan mereka yang berbeda-beda.

Proses penyebaran penduduk di Indonesia, baik sebelum maupun sesudah kemerdekaan tampak sangat dilematis atau paradoksal. Menurut Mohtar Naim, situasi paradoksal yang selama ini kita hadapi di Indonesia adalah bahwa di daerah-daerah yang seharusnya rakyatnya banyak merantau atau berpindah ke tempat lain, mereka enggan pergi merantau. Sebaliknya, di daerah-daerah di mana rakyatnya tidak seharusnya pergi merantau justru di daerah-daerah itu yang rakyatnya banyak pergi merantau. Sehingga apa yang kita saksikan ialah bahwa di daerah-daerah perantau, rakyatnya relatif makin berkurang sedang di daerah-daerah yang rakyatnya bukan perantau rakyatnya relatif bertambah (Kesuma, 2004:1).

Merantau atau pindah ke daerah lain untuk menemukan suatu kehidupan yang lebih baik telah dilakukan oleh masyarakat Indonesia sejak zaman nenek moyang. Pada zaman dulu, ketika suatu masyarakat melakukan pelayaran meninggalkan kampung halaman mereka menuju ke suatu tempat atau daerah lain dengan tujuan berdagang dan setelah itu menetap di daerah tersebut maka hal itu pun telah menjadi suatu kegiatan perpindahan penduduk yang biasanya disebut migrasi.

Menurut Hartono dan Aziz (2008:19), migrasi adalah gejala gerak horinsontal untuk pindah tempat dan pindahnya tidak terlalu dekat, melainkan melintasi batas administrasi, pindah ke unit administrasi lain, misalnya kelurahan, kabupaten, kota atau negara. Dengan kata lain, migrasi merupakan perpindahan penduduk dari satu unit geografis ke unit geografis lainnya.

PBB (Perserikatan Bangsa Bangsa), menyatakan bahwa migrasi adalah suatu perpindahan tempat tinggal dari suatu unit administratif ke unit administratif lainnya. Konsep migrasi di atas mengandung pengertian bahwa perubahan tempat tinggal secara permanen, tidak memberikan batasan pada jarak maupun sifat kepindahan tersebut. Usaha untuk mengembangkan konsep migrasi ternyata tidak menghasilkan suatu rumusan yang seragam. Suatu hal yang nampaknya disepakati bersama adalah migrasi menyangkut perubahan tempat tinggal dari yang biasanya.

Berdasarkan pada konsep migrasi tadi juga, ternyata dalam kehidupan orang Minangkabau lebih mengenal konsep migrasi dengan sebutan merantau. Merantau yang dilakukan oleh orang Minangkabau sudah terjadi sejak dulu. Pada masa lalu, orang 
Minangkabau telah membagi alam Minangkabau menjadi dua kawasan yaitu kawasan pegunungan (darek) dan kawasan pesisir (rantau). Kawasan darek dan rantau merupakan dua kawasan yang menjadi satu dalam kesatuan alam Minangkabau.

Pada masa itu juga, banyak sekali orang Minangkabau yang ada di kawasan pegunungan (darek) pergi ke daerah pesisir (rantau), Karena daerah pesisir telah menjadi kawasan perdagangan rempah-rempah yang dilakukan oleh para pedagang dari Asia. Peristiwa itulah yang merupakan awal mulanya orang Minangkabau melakukan perantauan (Muarif, 2009:40)

Menurut Gunawan Fauzi, merantau adalah penjelajah atau hijrah untuk membangun kehidupan yang lebih baik. Dalam alam pikiran orang Minangkabau, kampung halaman diibaratkan sebagai lahan persemaian. Kampung halaman berfungsi untuk menumbuhkan bibit-bibit. Setelah bibit-bibit tumbuh, kemudian harus dikeluarkan dari persemaian. Bibit-bibit harus diletakan pada lahan yang lebih luas. Tujuannya agar dapat tumbuh menjadi besar. Anak-anak Minangkabau adalah bibit-bibit yang telah tumbuh di persemaian alam Minangkabau. Para bujang harus menempuh proses merantau, mereka harus dipindahkan pada lahan lain yang lebih luas (Muarif. 2009:52).

Migrasi orang Minangkabau terjadi besar-besaran pada abad ke-14, di mana banyak keluarga Minangkabau yang berpindah ke Negeri Sembilan, Malaysia. Kemudian gelombang migrasi berikutnya terjadi pada abad ke-19, yaitu ketika Minangkabau mendapatkan hak istimewa (privilege) untuk mendiami kawasan Kerajaan Riau-Lingga. Ada banyak penjelasan terhadap fenomena ini, salah satu penyebabnya ialah sistem kekerabatan matrilinial. Pada sistem kekerabatan ini, penguasaan harta pusaka dipegang oleh kaum perempuan sedangkan hak kaum pria cukup kecil. Fenomena ini yang menyebabkan kaum laki-laki Minangkabau memilih untuk merantau. Selain itu juga, pertumbuhan penduduk yang tidak diiringi dengan bertambahnya sumber daya alam yang dapat di olah. Faktor-faktor inilah yang kemudian mendorong orang Minangkabau pergi merantau mengadu nasib di negeri orang (Padusi, 2009:2-3).

Seperti halnya yang terjadi di Kota Ambon saat ini, berdasarkan hasil pengamatan (observasi) awal yang Penulis lakukan, terlihat bahwa banyak orang Minangkabau yang datang kemudian melakukan aktivitas perdagangan, seperti membuka usaha warung makan atau yang biasa disebut Rumah Makan Padang. Selain itu, mereka juga berusaha dengan menjual pakaian atau menjual sate Padang. Profesi ini hanya dilakukan oleh 
beberapa orang saja. Ada juga di antara mereka yang telah bekerja sebagai Pegawai Negeri, Guru sekolah, TNI, Polisi, dan lain-lain.

Kota Ambon merupakan salah satu Kota Kolonial di Indonesia. Kota Kolonial adalah kota yang dibentuk oleh para pendatang dari barat. Pada masa kolonial, wilayah Kota Ambon sebagian besar dihuni oleh para pendatang dari berbagai etnis. Hal ini dapat di buktikan dengan hasil perhitungan penduduk yang dilakukan oleh Gerrit Knaap seorang sejarawan Belanda. Menurut perhitungan Knaap, jumlah penduduk Kota Ambon pada masa kolonial, dari $100 \%$ penduduk Kota Ambon hanya sekitar 5\% saja yang orang Ambon sisanya yang 95\% adalah para pendatang. Menurut perhitungan penduduk ("Proto-census") yang dilakukan VOC dalam tahun 1694, jumlah penduduk Kota Ambon adalah 4.487 jiwa maka jumlah penduduk lokal hanya sebanyak 274 jiwa (5\%) saja. Dari faktor itu, Knaap menyebutkan Kota Ambon pada masa itu sebagai "City of migrant" (Leirissa et al, 2004:63).

Orang Minangkabau pertama kali datang ke Kota Ambon pada tahun 1920-an, namun tidak sampai seminggu di Kota Ambon mereka sudah dibawa ke Pulau Saparua oleh bangsa Belanda dan mereka ini merupakan generasi pertama orang Minangkabau yang datang ke Kota Ambon. Generasi ke-2 orang Minangkabau yang datang ke Kota Ambon pada tahun 1950 dan hanya berjumlah 20 orang. Sebagian dari mereka berprofesi sebagai pedagang dan sampai saat ini orang Minangkabau yang ada di Kecamatan Sirimau Kota Ambon berjumlah 957 jiwa dengan 400 KK (Kepala Keluarga). Jumlah ini merupakan data sementara yang diperoleh dari Ketua Organisasi IKM (Ikatan Keluarga Minangkabau).

Sampai saat ini Kota Ambon telah menjadi daerah berkumpulnya para pendatang dari berbagai etnis. Etnis-etnis tersebut di antaranya adalah etnis Cina, etnis Arab, etnis Bugis, etnis Buton, etnis Jawa, etnis Minangkabau dan lain-lain. Sebagai kota para pendatang dan kota perdagangan maka Kota Ambon pada umumnya memiliki daya tarik tersendiri bagi para pendatang, yang salah satunya adalah etnis Minangkabau. Berdasarkan pada berbagai latar belakang sistem sosial budaya yang dimiliki oleh para etnis pendatang maka dapat dikatakan bahwa saat ini Kota Ambon merupakan sebuah kota multikultural. Acuan utama bagi terwujudnya masyarakat kota Ambon yang multikultural adalah multikulturalisme, yaitu sebuah idiologi yang mengakui dan mengagungkan perbedaan dalam kesederajatan baik secara individu maupun secara kebudayaan (Fay 1996, Jary dan Jary 1991, Watson 2000 dalam Suparlan 2004 : 281). 
Orang Minangkabau yang bermigrasi ke Kota Ambon saat ini, memiliki berbagai latar belakang sistem sosial budaya yang dibawa dari kampung halaman, yang pada akhirnya akan melebur dengan sistem sosial budaya masyarakat Kota Ambon pada umumnya. Dikhawatirkan suatu saat akan terjadi pergeseran atau bahkan hilangnya nilainilai sosial budaya dari kedua masyarakat tersebut.

Gelombang migrasi orang Minangkabau ke Kota Ambon mengalami perkembangan yang cukup signifikan karena adanya peluang pengembangan ekonomi pasca konflik. Perkembangan ini ditandai dengan begitu banyaknya rumah makan Padang di Kota Ambon yang muncul pasca konflik, yaitu sebanyak 24 (dua puluh empat) unit. Ini sangat berbeda dengan situasi sebelum konflik karena jumlahnya hanya sekitar 5 (lima) unit yang terletak di wilayah Kecamatan Sirimau kota Ambon. Permasalahan utama dalam penelitian ini adalah apa faktor penyebab orang Minangkabau bermigrasi ke Kota Ambon? Bagaimana pola adaptasi orang Minangkabau di Kota Ambon? Tujuan dari penelitian ini adalah untuk mendeskripsikan motivasi orang Minangkabau bermigrasi ke Kota Ambon. Untuk mendeskripsikan pola adaptasi orang Minangkabau di Kota Ambon, dan untuk mendeskripsikan faktor penyebab orang Minangkabau tetap eksis di Kota Ambon.

\section{Metode Penelitian.}

Dalam penelitian ini, metode yang digunakan adalah metode penelitian kualitatif yang lebih difokuskan pada aspek Sosiologi Perkotaan. Melalui metode ini, peneliti mencoba untuk mendeskripsikan berbagai realitas sosial budaya dan ekonomi, khususnya tentang migrasi orang Minangkabau di Kota Ambon. Kecamatan Sirimau dipilih sebagai lokasi penelitian dengan beberapa alasan, diantaranya seperti; 1) Kecamatan Sirimau merupakan salah satu dari 5 kecamatan di Kota Ambon dan merupakan wilayah pusat kota. 2) sebagai wilayah pusat kota, maka banyak ditemukan orang Minangkabau yang menjalankan usaha perdagangannya sehingga sangat mempermudah kegiatan penelitian.

Kegiatan pengumpulan data diawali dengan langkah penentuan informan. Usaha untuk menemukan informan dapat dilakukan dengan cara, (1) melalui keterangan orang yang berwenang, baik secara formal (pemerintah) maupun secara informal (pimpinan masyarakat, seperti tokoh masyarakat, pimpinan adat dan lain-lain), (2) melalui wawancara pendahuluan yang dilakukan peneliti (Maleong, 2005:132-133). 
Guna memperoleh data yang banyak dan benar tadi maka peneliti menggunakan teknik snowball sampling. Menurut Coleman, teknik snowball sampling artinya menanyakan kepada informan siapa saja yang menjadi teman terdekatnya. Kepada temanteman terdekat itu ditanyakan lagi siapa teman terdekatnya. Demikian seterusnya sehingga akan diperoleh informasi dari sejumlah informan yang relatif besar (Ritzer, 2007:31).

Berdasarkan pada teknik snowball sampling yang digunakan, maka peneliti menggunakan 16 orang informan yang kemudian peneliti tetapkan sebagai informan kunci (key person). Peneliti berharap dengan jumlah informan yang ditetapkan ini, peneliti dapat memperoleh data serta informasi yang benar guna penulisan selanjutnya. Dengan menggunakan metode penelitian kualitatif maka teknik pengumpulan data yang dilakukan oleh peneliti diantaranya yaitu, pengamatan langsung, wawancara tidak terstruktur (bebas) serta penelaah kepustakaan. Data yang telah terkumpul dalam kegiatan penelitian kemudian akan dianalisis dengan menggunakan teknik analisis data kualitatif. Menurut Miles dan Huberman (2007:16-17), proses analisis data kualitatif berlangsung melalui tiga alur kegiatan yang terjadi secara bersamaan yaitu, reduksi data, penyajian data, penarikan kesimpulan atau verifikasi.

\section{Temuan dan Pembahasan.}

Kota Ambon merupakan ibukota Provinsi Maluku yang secara administratif memiliki batas-batas sebagai berikut; Sebelah Utara berbatasan dengan petuanan Desa Hitu, Desa Hila, Desa Kaitetu, Kecamatan Leihitu, Kabupaten Maluku Tengah. Sebelah Selatan berbatasan dengan Laut Banda. Sebelah Timur berbatasan dengan petuanan Desa Suli, Kecamatan Salahutu Kabupaten Maluku Tengah. Sebelah Barat berbatasan dengan petuanan Desa Hatu, Kecamatan Leihitu Barat Kabupaten Maluku Tengah. Dengan batasbatas tersebut maka Kota Ambon memiliki luas wilayah sebesar 359,45 $\mathrm{Km}^{2}$. Kota Ambon memiliki 5 (lima) kecamatan yaitu; Kecamatan Nusaniwe, Kecamatan Sirimau, Kecamatan Leitimur Selatan, Kecamatan Teluk Ambon Baguala, dan Kecamatan Teluk Ambon. Masing-masing kecamatan memiliki jumlah penduduk sebagai berikut: Kecamatan Nusaniwe, jumlah penduduknya sebanyak 98417 jiwa, Kecamatan Sirimau jumlah penduduknya sebanyak 166397 jiwa, Kecamatan Leitimur Selatan jumlah penduduknya sebanyak 10302 jiwa, Kecamatan Teluk Ambon Baguala jumlah penduduknya sebanyak 61658 jiwa, dan Kecamatan Teluk Ambon jumlah penduduknya sebanyak 47358 jiwa. Dengan jumlah penduduk setiap kecamatan tersebut maka total 
penduduk Kota Ambon sebanyak 384132 jiwa. Keseluruhan jumlah penduduk Kota Ambon ini terbagi menurut jenis kelamin laki-laki sebanyak 192836 dan perempuan sebanyak 384132 jiwa. Berdasarkan penelitian tentang migrasi orang Minangkabau di Kota Ambon maka dapat dijelaskan sebagai berikut:

\subsection{Faktor Penyebab Orang Minangkabau Migrasi Ke Kota Ambon.}

Migrasi atau perpindahan penduduk dapat disebabkan oleh beberapa faktor, seperti umumya diketahui ada faktor pendorong (push factor) dan faktor penarik (pull factor). Teori dorong-tarik pertama kali dikemukakan oleh Everett S. Lee pada tahun 1966 namun hingga sekarang masih dianggap relevan. Dalam teorinya, Lee mengemukakan adanya 4 faktor yang berpengaruh terhadap seseorang dalam mengambil keputusan untuk bermigrasi yaitu; 1) faktor-faktor yang terdapat di daerah asal, 2) faktor-faktor yang terdapat di daerah tujuan, 3) faktor-faktor rintangan, dan 4) faktor-faktor pribadi. Faktorfaktor yang terdapat di daerah asal biasanya merupakan faktor pendorong seseorang pergi meninggalkan kampung halamannya ke daerah lain. Faktor-faktor tersebut seperti, keterbatasan dan kerusakan sumberdaya alam yang disebabkan oleh banjir, erosi tanah, kekeringan, konflik sosial, politik dan agama. Sedangkan faktor-faktor yang terdapat di daerah tujuan biasanya merupakan faktor penarik seseorang untuk bermigrasi diantaranya seperti, penemuan sumberdaya alam (pertambangan), industri-industri baru, dan keadaan iklim serta lingkungan yang menyenangkan untuk di tempati.

Hasil penelitian Yunus (1991) menemukan bahwa, faktor pendorong dan faktor penarik yang kemudian menyebabkan penduduk dan fungsi-fungsi kota tertentu memilih daerah pinggiran kota sebagai tujuan tetapnya, yaitu faktor pendorong yang berhubungan dengan daerah asal dan faktor penarik berkaitan dengan daerah tujuan (Koestoer, 2001: 97). Penelitian lain juga menunjukan bahwa orang-orang desa yang miskin "didorong" pindah ke kota karena kemandekan atau berkurangnya kesempatan kerja di desa, dan pada saat yang sama "tertarik" oleh harapan untuk mendapat pekerjaan yang lebih baik dan penghasilan lebih tinggi (Manning dan Effendi, 1985: 10-11). Dalam pandangan Marx, faktor pendorong dan faktor penarik tadi biasanya lebih berhubungan dengan sektor sosial ekonomi suatu masyarakat. Keterbatasan sumberdaya alam suatu daerah (desa) akan sangat berpengaruh kepada masyarakat desa tersebut dalam upaya untuk memenuhi kebutuhan hidup, sehingga mereka akan pergi ke daerah atau kota lain untuk memenuhi kebutuhan hidup itu. 
Daya tarik kota seperti tersedianya pabrik-pabrik serta industri-industri skala besar yang sangat membutuhkan sumber daya manusia atau para pekerja yang banyak, kemudian akan menarik para pekerja dari desa ke kota untuk bekerja walau hanya dengan upah yang sangat rendah. Realitas seperti ini yang dalam pandangan Marx dikenal sebagai sistem kapitalisme dunia, dimana para pekerja (kaum proletariat) bekerja keras dengan upah yang sangat minim hanya untuk memberikan kekayaan kepada para pemilik modal (kaum borjuis). Dalam sistem kapitalisme ini, telah terjadi berbagai penghisapan (eksploitasi) dalam berbagai aspek seperti tenaga, pikiran, waktu dan lain-lain. Sistem kapitalisme ini biasanya lebih sering terjadi dalam kehidupan masyarakat dunia ketiga atau negara-negara berkembang seperti Indonesia. Migrasi orang Minangkabau ke Kota Ambon bukan disebabkan oleh sistem kapitalisme tadi, atau bukan juga karena faktor sosial ekonomi saja tetapi juga terjadi karena faktor budaya, politik, dan pendidikan. Terkait akan faktor-faktor tadi maka supaya lebih jelasnya dapat dilihat pada penjelasan berikut ini; Terkait dengan penjelasan tersebut maka migrasi orang Minangkabau ke Kota Ambon disebabkan oleh dua faktor tadi yaitu faktor pendorong dan faktor penarik. Faktor pendorong yang menyebabkan orang Minangkabau bermigrasi ke Kota Ambon adalah sebagai berikut; 1) adanya determinasi penjajah Belanda di daerah Minangkabau pada tahun 1920 dan membawa paksa beberapa orang laki-laki Minangkabau ke Kota Ambon sebagai pekerja karena ambisi penjajah Belanda saat itu untuk menguasai rempah-rempah di Pulau Ambon. Mereka inilah yang merupakan generasi pertama orang Minangkabau migrasi ke Kota Ambon. 2) adanya pertentangan antara adat dan Islam, 3) kurangnya daya dukung alam (lahan yang tersedia hanya dijadikan sawah sedangkan kaum laki-laki banyak yang tidak bisa mengolah sawah. 4) adanya upaya untuk mencari nafkah bagi pemenuhan kebutuhan hidup kelaurga. Sedangkan faktor penariknya adalah sebagai berikut; 1) Kota Ambon sejak dahulu sudah dikenal sebagai kota perdagangan, 2) karakter hidup warga Kota Ambon yang ramah, 3) sifat orang Ambon yang konsumtif (suka berbelanja)

\subsection{Pola Adaptasi Orang Minangkabau di Kota Ambon.}

Adaptasi sosial (social adaptation) adalah kemampuan atau kecenderungan individu atau masyarakat dalam menyesuaikan diri dengan lingkungan baru untuk tetap hidup dengan baik. Dalam Kamus Sosiologi karangan Mustofa dan Maharani menyatakan bahwa adaptasi adalah 1) proses mengatasi halangan-halangan dari lingkungan; 2) memanfaatkan sumber-sumber yang terbatas untuk kepentingan lingkungan dan sistem; 
3) proses perubahan untuk menyesuaikan dengan situasi yang berubah; 4) penyesuaian dari kelompok terhadap lingkungan; 5) penyesuaian pribadi terhadap lingkungan; 6) penyesuaian biologis atau budaya sebagai hasil seleksi ilmiah. Orang Minangkabau merupakan salah satu suku perantau di Indonesia yang melakukan adaptasinya dengan sangat baik. Pola adaptasi yang mereka terapkan dalam kehidupan sehari-hari di Kota Ambon adalah mereka dapat hidup menyebar atau berbaur dengan masyarakat Kota Ambon. Dalam pola adaptasi sosial yang mereka jalankan, mereka tidak pernah membedabedakan masyarakat Kota Ambon pada suku, agama, ras, dan golongan. Selain itu, mereka juga dapat terlibat dalam berbagai kegiatan sosial budaya yang dilakukan oleh masyarakat Kota Ambon, atau juga kegiatan-kegiatan sosial budaya yang mereka lakukan dan turut melibatkan masyarakat Kota Ambon. Realitas ini merupakan bagian dari ciri sifat budaya orang Minangkabau yang berubah dan bertahan, sesuai dengan situasi dan kondisi yang sedang terjadi.

Ada beberapa pepatah yang juga sering dipakai untuk menjadi pedoman beradaptasi dalam budaya merantau orang Minangkabau dimana saja mereka berada termasuk juga di Kota Ambon yaitu, "dimana bumi di pijak disitu langit dijunjung”, artinya dimana saja mereka merantau, mereka akan selalu menghormati orang lain. Pepatah lainnya seperti, "di kandang kambing mengembik, di kandang kerbau mengo'ek”, artinya dimana pun mereka berada, mereka selalu akan menghormati orang lain dan mengikuti segala aturan yang berlaku di daerah rantau.

Dengan pola adaptasi seperti itu, maka dari dulu sampai sekarang tidak pernah ditemukan ada pemukiman-pemukiman orang Minangkabau di Kota Ambon. Umumnya mereka membeli rumah pada daerah kota tetapi tidak terpusat pada satu daerah tertentu. Jadi, pada satu sisi, gerak pertumbuhan wilayah kota mengikuti gerak pemukiman penduduk dan pada sisi yang sama banyak lahan-lahan penduduk yang dijual oleh pemiliknya kepada siapa saja yang mampu membeli dan tentunya dengan harga yang sangat tinggi. Fenomena seperti ini sering terjadi dalam realita kehidupan masyarakat di Kota Ambon pada umumnya. Ternyata dengan pola adaptasi seperti ini, orang Minangkabau sangat menyadari akan keberadaan (eksistensi) mereka di Kota Ambon. Analisis eksistensi mereka tidak hanya membantu untuk mengungkap atau menjawab pertanyaan tentang apa (esensi)-nya tetapi lebih menukik pada substansi sosialnya untuk menjawab pertanyaan mengenai siapa, mengapa dan bagaimana hakikat diri mereka (Watloly, 2007:9). 
Kesadaran akan eksistensi yang dimiliki orang Minangkabau menyebabkan mereka dapat hidup berbaur dan bergaul secara baik dengan masyarakat Kota Ambon sehingga segala aktivitas serta usaha yang mereka lakukan dapat berjalan dengan baik pula. Dalam berbagai realitas hidup orang Minangkabau yang sudah lama merantau di Kota Ambon, ada pengakuan terhadap identitas etnis mereka sebagai orang Ambon. Pengakuan akan identitas etnis merupakan suatu tindakan langsung yang berasal dari dalam diri untuk menyatakan eksistensi mereka di Kota Ambon. Pengakuan akan identitas etnik tadi, berhubungan dengan pandangan Parson tentang dimensi moral dalam orientasi nilai. Dimensi moral ini, menunjuk pada standar-standar abstrak yang digunakan untuk menilai tipe-tipe tindakan alternatif menurut implikasinya terhadap sistem itu secara keseluruhan (baik individu maupun sosial) dimana tindakan itu berakar. Pengakuan akan identitas etnik dari orang Minangkabau sebagai orang Ambon, merupakan tindakan-tindakan yang muncul dari dalam diri mereka dan kemudian dinyatakan dalam interaksi mereka dengan masyarakat Kota Ambon.

DeVos (dalam Pelly, 1998:13-14) menyebutkan bahwa, identitas etnik, seperti identitas lainnya, bukan saja merupakan persoalan mengetahui siapa seseorang itu, tetapi juga masalah mengetahui bagaimana seseorang itu dipandang oleh orang lain. Identitas etnik memerlukan dipeliharanya perilaku yang cukup konsisten sehingga memungkinkan orang-orang lain untuk meletakan seseorang atau suatu kelompok ke dalam kategori sosial tertentu, dengan demikian memerlukan interaksi-interaksi yang diperlukan. Pengakuan akan identitas etnik merupakan suatu bukti dari pola adaptasi yang telah dijalankan orang Minangkabau di Kota Ambon. Walaupun dengan jumlah mereka yang terus bertambah, tetapi tidak menyebabkan mereka kemudian hidup berkelompok dalam suatu lokasi pemukiman tertentu di wilayah pusat atau di sekitar pinggiran Kota Ambon.

Pelly (1998:94-95) mengatakan bahwa populasi Minangkabau dari tahun ke tahun terus bertambah, setelah beberapa tahun berkembanglah kerumunan kampung-kampung etnik Minangkabau mengelilingi pusat-pusat perbelanjaan tersebut. Pendapat yang diungkapkan Pelly tadi, sesuai dengan realitas serta hasil penelitian yang dilakukan di Kota Medan. Pendapat ini juga sangat mendukung konsep misi budaya yang digunakan Pelly dalam melihat tentang pola adaptasi sosial orang Minangkabau di Kota Medan pada masa itu. Misi budaya didefenisikan Pelly sebagai seperangkat tujuan yang diharapkan 
dicapai oleh anggota-anggota suatu masyarakat tertentu yang didasarkan pada nilai-nilai dominan dari pandangan dunia masyarakat tersebut.

Temuan serta konsep misi budaya yang disampaikan Pelly dalam hasil penelitian di Kota Medan merupakan suatu realitas objektif yang terjadi atau di alami oleh orang Minangkabau di Kota Medan saat itu. Realitas objektif ini menunjuk pada situasi dan kondisi Kota Medan yang merupakan salah satu bagian dari kota-kota besar di Indonesia dan sangat memungkinkan bagi para perantau Minangkabau untuk membentuk pemukiman-pemukiman mereka mengelilingi kota. Berdasarkan pada pola adaptasi sosial tadi maka akan sangat mudah bagi para perantau Minangkabau untuk melaksanakan apa yang disebut Pelly dengan misi budaya tadi.

Realitas objektif yang di alami oleh suatu masyarakat pada suatu waktu tertentu serta suatu daerah atau kota tertentu, pasti belum tentu sama dengan realitas objektif yang di alami oleh masyarakat tersebut pada waktu yang berbeda serta di daerah atau kota yang berbeda pula. Dalam pandangan Berger Luckhmman tentang the social construction of reality menyatakan bahwa realitas sosial yang di alami oleh setiap individu itu berlangsung setiap hari dalam hidupnya (everyday life). Jadi, dapat dikatakan bahwa tindakan setiap individu dalam hidupnya, pada waktu-waktu sebelumnya belum tentu sama dengan waktu sekarang dan waktu-waktu yang akan datang. Dalam realitas hidup orang Minangkabau di Kota Ambon telah menampilkan suatu perwujudan dari pola adaptasi sosial mereka selama ini. Realitas objektif yang kemudian tampak adalah tidak pernah ditemukan mereka membuat kampung atau tidak terdapat pemukiman-pemukiman yang khusus dihuni oleh orang Minangkabau serta letaknya mengelilingi pemukiman etnis lain di Kota Ambon. Pada umumnya rumah-rumah orang Minangkabau itu menyebar dalam lingkungan tempat tinggal masyarakat Kota Ambon.

Dalam pemikiran orang Minangkabau bahwa dengan hidup menyebar serta berbaur dengan masyarakat Kota Ambon maka mereka akan mendapatkan pengetahuanpengetahuan baru yang mungkin saja selama di kampung halaman mereka, hal itu tidak pernah ditemukan. Selain itu juga, mereka akan memperoleh berbagai informasi penting yang berhubungan dengan upaya untuk menjalankan usaha perdagangan. Mereka menyadari bahwa dengan pola adaptasi seperti itu maka tujuan merantau yang mereka harapkan dapat tercapai dengan baik. Pola adaptasi yang dilakukan orang Minangkabau telah membuktikan bahwa mereka menyadari akan keberadaan (eksistensi) mereka di Kota Ambon. Keberadaan ini merupakan sebuah realitas yang betul-betul tampak dan 
bukan hanya sekedar mimpi. Dalam realitas seperti ini orang Minangkabau menyadari bahwa mereka telah menjadi bagian dari kehidupan masyarakat Kota Ambon.

\section{Kesimpulan.}

Berbagai studi Sosiologi Perkotaan telah dijelaskan tentang faktor-faktor pendorong (push factor) dan faktor-faktor penarik (pull factor). Faktor-faktor pendorong (push factor) tadi biasanya berhubungan dengan daerah asal atau kampung halaman para perantau. Sedangkan faktor-faktor penarik (pull factor) biasanya berasal dari daerah tujuan para perantau. Faktor pendorong orang Minangkabau merantau ke Kota Ambon adalah adanya determinasi penjajahan bangsa Belanda di daerah mereka, adanya pertentangan antara adat dengan agama Islam, terbatasnya sumberdaya alam (tanah) yang hanya dapat di olah untuk persawahan, mencari nafkah serta mencari pengalaman hidup yang baru. Faktor penarik orang Minangkabau bermigrasi ke Kota Ambon adalah, Kota Ambon dari dulu terkenal sebagai kota para pendatang (city of migrant), Kota Ambon juga terkenal sebagai kota perdagangan, sikap hidup masyarakat Kota Ambon yang ramah, serta sifat hidup masyarakat Kota Ambon yang suka berbelanja (konsumtif).

Faktor-faktor inilah yang kemudian menjadi faktor penyebab orang Minangkabau bermigrasi ke Kota Ambon. Migrasi atau merantau bagi orang Minangkabau di Kota Ambon adalah pergi meninggalkan kampung halaman untuk mencari nafkah. Migrasi atau merantau orang Minangkabau ke Kota Ambon lebih bersifat parmanen, artinya bahwa sebagian besar dari mereka lebih memilih menetap di Kota Ambon. Walaupun memang ada juga yang pulang untuk menjenguk keluarga di kampung halaman, tetapi setelah itu mereka akan kembali lagi ke Kota Ambon. Selain mereka yang menetap karena telah berhasil di Kota Ambon, ada juga yang tidak berhasil dan memilih pergi ke daerah lain untuk merantau.

Tujuan migrasi atau merantau mereka ke Kota Ambon adalah untuk meningkatkan kesejahteraan hidup keluarga serta untuk menemukan pengalaman hidup yang baru. Menurut orang Minangkabau yang merantau di Kota Ambon, di kampung halaman sudah sangat susah untuk meningkatkan kesejahteraan hidup keluarga karena banyak sekali persaingan serta tidak adanya pengetahuan baru yang diperoleh. Dalam perantauan mereka, orang Minangkabau merupakan salah satu etnis yang mempunyai kemampuan beradaptasi dengan lingkungan baru atau daerah rantau yang sangat baik. Hal ini merupakan suatu realitas yang kita temui dalam kehidupan orang Minangkabau di Kota 
Ambon. Pola adaptasi orang Minangkabau di Kota Ambon sampai sekarang terlihat sangat baik. Mereka bisa hidup bersama menyebar dan berbaur dengan masyarakat Kota Ambon. Dalam beradaptasi tidak pernah ditemukan ada pemukiman-pemukiman orang Minangkabau atau tidak ditemukan ada orang-orang Minangkabau yang membuat kampung sendiri. Pola adaptasi seperti ini yang menyebabkan orang Minangkabau bisa diterima oleh masyarakat Kota Ambon dan mereka juga bisa hidup dengan nyaman dan tenang untuk menjalankan tujuan perantauan mereka. Berdasarkan pola adaptasi sosial tadi maka interaksi sosial yang di lakukan oleh orang Minangkabau dengan masyarakat Kota Ambon juga berjalan dengan harmonis. Dalam menjalankan usaha perdagangan di Kota Ambon, mereka juga memakai tenaga kerja yang bukan saja berasal dari Minangkabau tetapi masyarakat Kota Ambon. Kenyataan akan suatu interaksi sosial ini juga nampak dalam berbagai kegiatan sosial budaya yang dilakukan oleh orang Minangkabau juga turut melibatkan masyarakat Kota Ambon. Sebaliknya mereka juga turut terlibat dalam berbagai kegiatan sosial budaya yang di laksanakan oleh pemerintah maupun masyarakat Kota Ambon.

Keharmonisan hidup yang diwujudkan dalam interaksi antara orang Minangkabau dan masyarakat Kota Ambon ternyata sangat mendukung segala kegiatan usaha yang akan dijalankan orang Minangkabau. Orang Minangkabau percaya bahwa dengan hidup menyebar serta bergaul dengan masyarakat Kota Ambon secara baik maka akan mempermudah mereka untuk mencapai suatu kesuksesan yang diharapkan. Seperti sebuah kesuksesan yang dimaknai oleh orang Minangkabau sebagai suatu kenyamanan serta ketenangan hidup. Kesuksesan bagi mereka bukan saja karena memiliki mobil mewah, rumah bertingkat serta ruko (rumah toko) sebanyak tiga unit. Orang Minangkabau merupakan salah satu etnis perantau yang terkenal ada dimana-mana serta meraih sukses dalam berbagai sektor kehidupan. Walaupun ada juga di antara mereka yang gagal dalam menjalani perantauan, tetapi itu hanya sebagian kecil saja. Hal ini merupakan suatu realitas hidup yang selalu di alami oleh setiap masyarakat perantau di Nusantara. Ada yang sukses tetapi juga pasti ada yang mengalami kegagalan, itulah realita. 


\section{Daftar Pustaka}

Adisasmita Raharjo, (2008), 'Pengembangan Wilayah, Konsep dan Teori, Cetakan I, Penerbit Graha Ilmu, Yogyakarta.

Berger Peter. L dan Luckmann Thomas, (1990), 'Tafsir Sosial Atas Kenyataan,(Sebuah risalah tentang Sosiologi Pengetahuan), Cetakan I, Penerbit LP3ES, Jakarta

Berry David, (2003), 'Pokok-Pokok Pikiran Dalam Sosiologi', Cetakan Ke-IV, Penerbit PT RadjaGrafindo, Jakarta.

Colombijn Freek, (2006), 'Paco-Paco (Kota) Padang, Sejarah Sebuah Kota Di Indonesia Pada Abad Ke-20 Dan Penggunaan Ruang Kota,' Cetakan I, Penerbit Ombak, Yogyakarta.

Evers Hans-Dieter, (1982), 'Sosiologi Perkotaan, (Urbanisasi dan Sengketa Tanah di Indonesia dan Malaysia)', Cetakan I, Penerbit LP3ES, Jakarta.

Evers Hans-Dieter dan Korff Rudiger, (2000), 'Southeast Asia Urbanism' (The Meaning and Power of Sosial Space) LIT Verlag, Muenster-Humburg-London.

Hakimy Idrus, Dtk Rajo Penghulu, (1997), Rangkaian Mustika Adat Basandi Syarak Di Minangkabau, Cetakan VII, Penerbit PT. Remaja Rosdakarya, Bandung.

Hartomo.H dan Arnicun Aziz, (2008), 'Ilmu Sosial Dasar', Cetakan VII, Penerbit PT. Bumi Aksara, Jakarta.

Johnson, Doyle Paul, (1999), 'Teori Sosiologi Klasik dan Modern', Penerbit Pustaka Pelajar.

Kausar AS, (2009), 'Sistim Birokrasi Pemerintahan di Daerah Dalam Bayang-Bayang Budaya Patron-Klien', Cetakan I, Penerbit PT. Alumni, Bandung.

Kesuma Ima Andi, (2004), 'Migrasi dan Orang Bugis', Cetakan II, Penerbit Ombak, Yogyakarta.

Koestoer Raldi Hendro, dkk (2001), 'Dimensi Keruangan Kota, Teori dan Kasus', Cetakan I, Penerbit Universitas Indonesia, Jakarta.

Koentjaraningrat, (2005), 'Pengantar Antropologi', Jilid I, Cetakan III, Penerbit PT. Rineka Cipta, Jakarta.

Kopi Kadai, (2009), (update 20 Februari 2009), 'Generasi Minang Masa Kini', http://kadaikopi.carpediem123.com/?p=1545

Lawang Robert, (2008), 'Materi Perkuliahan, Konsep-Konsep Dasar Sosiologi (Max Weber)

Leirissa, dkk, (2004), 'Ambonku; Doeloe, Kini, Esok, Cetakan I, Pemerintah Kota Ambon. 
Maarif Ahmad Syafii, dkk (2010), 'Politik Identitas Dan Masa Depan Pluralisme Kita', Cetakan I, Penerbit Pusat Studi Agama dan Demokrasi (PUSAD) Yayasan Wakaf Paramadina, Jakarta.

Manning Chris dan Effendi Tadjuddin Noer (1985), 'Urbanisasi, Pengangguran, dan Sektor Informal di Kota, Penerbit PT Gramedia, Jakarta.

Miles, Matthew B. dan A. Michael Huberman, (1992), 'Analisis Data Kualitatif', Cetakan I, Penerbit Universitas Indonesia (UI-Press), Jakarta.

Moleong, J. Lexy, (2000), 'Metodologi Penelitian Kualitatif ', Cetakan ke-13, Penerbit Remaja Rosdakarya, Bandung. (2005), 'Metodologi Penelitian Kualitatif ', Cetakan ke-21, Penerbit Remaja

Rosdakarya, Bandung.

Muarif, (2009), 'Rahasia Suskses Orang Minang Di Perantauan', Cetakan I, Penerbit Pinus Book Publisher, Yogyakarta.

Mustofa Bisri dan Maharani Eilsa Vindi, (2008), 'Kamus Lengkap Sosiologi', Cetakan I, Penerbit Panji Pustaka, Yogyakarta.

Naim Mochtar, (1979), 'Merantau, Pola Migrasi Suku Minangkabau', Penerbit Gadjah Mada University Press, Yogyakarta.

Padusi, (Updated Februari 2009)' Sekilas Tentang Minangkabau Sumatera Barat' http://www.padusi.com/ani/files/article

Pelly Usman, (1998), 'Urbanisasi dan Adaptasi (Peranan Misi Budaya Minangkabau dan Mandailing)', Cetakan II, Penerbit Pustaka LP3ES, Jakarta.

Poloma Margaret M, (2010), 'Sosiologi Kontemporer', Cetakan ke-8, Penerbit PT RajaGrafindo Persada, Jakarta.

Pratita Suluh, (2008), (update 7 September 2008), 'Bisnisnya kaum Migran', http://suluhpratita.com/?tag=migrasi

Ralahalu Karel Albert, (2006), 'Otonomi Daerah Di Tengah Konflik'.

Rahmawati Mila, (2009), 'Sukses Bisnis Rumah Makan Padang', Cetakan I, Penerbit PT. Niaga Swadaya, Jakarta.

Ranjabar Jacobus, (2006), 'Sistim Sosial Budaya Indonesia (Suatu Pengantar)', Cetakan I, Penerbit Ghalia Indonesia, Bogor.

Ritzer George dan Goodman J. Douglas, (2004), 'Sociological Theory', New York. Ritzer George, (2007), 'Sosiologi Ilmu Pengetahuan Berparadigma Ganda', Penerbit PT. RajaGrafindo Persada, Jakarta. 
Rusdianta Syarbaini Syahrial, (2009), 'Dasar-Dasar Sosiologi', Cetakan I, Penerbit Graha Ilmu, Jakarta.

Rustanto Bambang, (2008), 'Studi Tentang Reposisi Perempuan Dalam Konteks Politik Nagari', Disertasi Doktoral Sosiologi UI.

Sinulingga, Budi D, (2005), 'Pembangunan Kota, Tinjauan Regional Dan Lokal,' Cetakan II, Penerbit Pustaka Sinar Harapan, Jakarta.

Soekanto Soerjono, (2002), 'Sosiologi Suatu Pengantar', Cetakan ke-33, Penerbit PT. RajaGrafindo Persada, Jakarta.

Somantri, R Gumilar, (2007), 'Migration Within Cities: A Study Of Socio-economic Processes, Intra-City Migration, And Grass-Roots Politics In Jakarta, 'Penerbit Fakultas Ekonomi Universitas Indonesia, Jakarta.

Suparlan Parsudi, (2004), 'Hubungan Antar-Sukubangsa', Cetakan I, Penerbit Yayasan Pengembangan Kajian Ilmu Kepolisian (YPKIK), Jakarta.

Suseno, Frans Magnis, (2005), 'Pemikiran Karl Marx, Dari Sosialisme Utopis ke Perselisihan Revisionisme', Cetakan VII, Penerbit PT. Gramedia Pustaka Utama, Jakarta. Turner Bryan. S dkk, (2010), 'Kamus Sosilogi', Cetakan I, Penerbit Pustaka Pelajar, Yogyakarta.

Usman A Rani, (2009), 'Etnis Cina Perantauan Di Aceh', Cetakan I, Penerbit Yayasan Obor Indonesia, Jakarta.

Usman Sunyoto, (2008), 'Pembangunan Dan Pemberdayaan Masyarakat', Cetakan V, Penerbit Pustaka Pelajar, Yogyakarta.

Watloly Aholiab, (2007), 'Filosofi Masyarakat Kepulauan, (Sebuah Telaah Filsafat

Dalam Rangka Indigenisasi Sosiologi Kepulauan)', Orasi Ilmiah Pada “DIES

NATALIS" UNPATTI Ke- 44. 